\title{
대외무상원조사업 평가보고서
}

I. 평가목적 및 방향

II. 2005년도 사업추진현황.

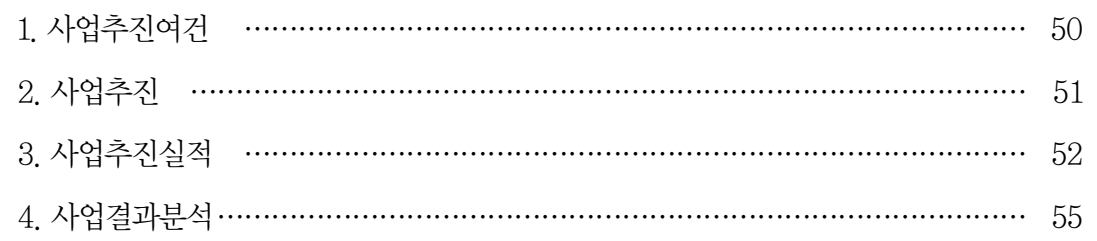

III. 평가 및 문제점

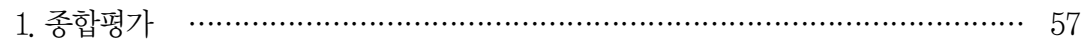

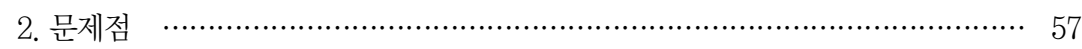

IV. 개선조치사항

1. 기조치사항중 정책부분 …………………………………………….... 62

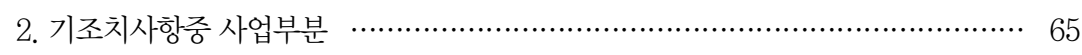

3. 향후 추진과제 …………………………………………………… 68

〈첨부〉 2005년도 $\mathrm{OECD/DAC}$ 회원국 $\mathrm{ODA}$ 지원현황(잠정) 


\section{I. 평가목적 및 방향}

- 2005년도를 중심으로 그간의 KOICA 사업을 종합적으로 평가

- 기존 사업방식에 대한 문제점과 개선방안 도출

- UN천년개발목표 (MDGs) 달성기여도 등 KOICA 원조의 국제적 수준 진단

※대부분의 선진공여국들은 MDGs 채택 이후 원 조정책의 기본방향과 시스템을 MDGs 달성을 위한 체제로 개편중

- 평가를 통해 노정된 문제점은 개선하고, 나아 가 전략적이고 미래지향적인 개발원조방향 정립

- 개도국의 빈곤문제를 근본적으로 해결해 나 가는 원조전략수립

- 지속발전 가능한 원조방향 및 원조기법 모색

- 국제사회와의 조화를 고려하되 우리만의 독 특한 경쟁력도 제고

- 내부평가를 통해 실질적이고 효과적인 업무 발전방안 도출

- 개발원조 내용과 형식을 선진원조형태로 발전 - 세계원조동향, KOICA 무상원조규모 증가, 추후 $\mathrm{OECD} / \mathrm{DAC}$ (개발원조위원회)가입 등 을 고려, 국제적으로 경쟁력있는 원조체제로 개편 ※N을 중심으로 국제사회는 $\mathrm{ODA}$ 의 확대 · 조직개편 및 전략수정 등 일련의 개혁 실시중 - 선진원조모델과 우리의 비교우위를 적절히 접목한 원조형태로 전환

\section{2005년도 사업추진현황}

\section{1. 사업추진여건}

- ODA 규모확대를 위한 국제사회 노력 가중

- '05. 9월, 제60차 UN정상회의에서 '06년부 터 MDGs를 포함한 국제개발목표 달성을 위 해 국별전략의 채택 및 실행을 결의 *2005년도 DAC 회원국의 ODA 지원규모 잠정

치는 1,065억불로 GNN대비 0.33\%

$\rightarrow$ 2000년 0.22\% 대비 0.11\%P 증가

- 개발재원 마련을 위해 $\mathrm{ODA}$ 확충에 대한 구 체 일정표에 합의

*2015년 ODA/GNI 0.7\% 달성을 위하여 2010년 까지 추가로 500 억불 지원 및 ODA/GNI 0.5\% 달성, 최빈국 지원 GNI 대비 $0.2 \%$ 까지 확대 - 우리정부는'05.11월, '국제개발협력 개선 종 합대책' 에서 MDGs 달성연도인 2015년을 목표로 ODA규모를 GNI대비 $0.25 \%$ 수준까 지 확대 검토방침 명시

- $\mathrm{ODA}$ 의 질적개선 요구

- $\mathrm{ODA}$ 양적확대는 물론, 질적 측면에서도 점 진적 - 단계적 언타이드화, 최빈국 지원강화, MDGs 달성 등 국제화 요구

- OECD는 2005년 2월 파리 고위급 포럼에서 ‘원조효과성 제고를 위한 파리선언’ 을 채택, 원조의 질적 개선을 위한 중점추진과제 도출 ※수원국의 주인의식 제고, 원조공여국간 원조절차 와 실행의 조화, 수원국의 개발전략과 공여국 원 조정책의 조율, 원조의 성과지향, 상호공동책임 등 
- 우리정부는 2010년을 전후로 OECD/DAC 가입을 추진 중이므로, $\mathrm{OECD}$ 기준에 부합 하는 원조내용으로 개선 필요

- 잦은 국제적 재난피해 발생

- 남아시아 지진해일, 파키스탄 지진, 중미 허 리케인 등 대형재난 발생

- 재난구호에 신속하고 효과적으로 대처 가능 한 사업수행체계 확립 필요

- 정부, 「국제개발협력 개선 종합대책」 수립 ('05. 11)

- 국무총리를 위원장으로 한 "국제개발협력위 원회" 설립 ('06. 1)

- 한국형 원조모델 정립, 추진시스템 개선, 효율성 제고, 인프라 구축, 국민 참여 확대를 골자로 한 개선방안수립

- 국민의 ODA 관심증대

- 해외봉사단파견 확대, 이라크 재건지원, 국 제재난구호 등으로 $\mathrm{KOICA}$ 사업 인지도 증가

- 국민의 관심증대는 사업구성과 내용이 국민 과 함께하는 형태로 변화될 것을 요구

\section{2. 사업추진}

\section{가. 사업목표}

- 개도국 빈곤퇴치를 위해 수원국의 자립능력 강화 집중지원

- 국제사회와 함께 MDGs 달성 등 세계적 이슈 해결 적극동참

- 우리나라 위상제고 및 개도국과의 우호협력 증진

\section{나. 중점추진방향}

- 개도국 Needs에 부합하고, 우리 개발경험 공 유 가능 사업 지원

- 인적자원개발(HRD) 및 정부역량강화

(Capacity Building) 중점지원

- 선진국 - 개도국간 지식 - 정보격차 해소를

위한 ICT 분야 지원강화

- 해외봉사단파견, NGO 지원, 홍보 등 국민참 여형 협력사업의 확대

- MDGs 등 국제사회 공동목표 지원강화

- 빈곤완화, 기초보건, 초등교육 등 $\mathrm{BHN}$ 분야 지원강화

- 여성, 환경 등 범지구적 과제에 대한 지원강화 - 최빈개도국 지원강화를 통한 세계빈곤해소 노력 동참

- 국제적 재난복구 및 재건지원 강화

- 이라크- 아프간 정부의 조기안정 중점지원

- 남아시아지진해일 등 복구사업에 대한 신속 하고 효율적인 지원

- 긴급구호봉사단 파견

\section{다. 국별 - 지역별 추진방향}

- 국별 · 지역별 최적배분 모색

- 국별특성, 양국관계, 협력효과 등을 감안, 중 점지원국가를 선정하고, 그 외 국가들에 대 해서는 기존 지원규모에서 적절배분

- ASEAN, APEC, SICA 등 지역 협의체 회원 국과의 협력강화

- 아시아지역 중점협력기조 유지 
- 우리나라와의 외교적 - 지리적 、 문화적 관계 고려

- 특히 아세안 및 아세안 후발개도국인 CLMV

※ 지원 강화

※ CLMA - 캄보디아, 라오스, 미얀마, 베트남

a 기타지역은 그 특성에 맞도록 지원

- 아프리카 지역은 사하라 이남을 중심으로 $\mathrm{BHN}$ 충족 및 $\mathrm{MDGs}$ 달성 위주의 인도주의 적 지원 확대

- 중남미 과테말라, 페루, 파라과이 등 중점협 력대상국은 보건, 교육 위주의 시설 및 인력
양성을 중점지원하고 기타 국가들은 $\mathrm{HRD}$ 위주지원

- 중앙아시아 지역은 시장경제 전환노력 중점 지원

\section{- 최빈국 지원비율 확대}

- 빈곤감소 등 $\mathrm{MDGs}$ 달성을 목표로 인도적 지원 확대

- 절대빈곤 퇴치를 위한 국제사회 노력 적극 동참

※ 우리나라의 GNI 대비 최빈국 지원비율은 $0.01 \%$ 로 DAC 회원국의 $1 / 8$ 수준

\section{3. 사업추진실적}

\section{가. 총괄}

\begin{tabular}{|c|c|c|c|}
\hline \multicolumn{2}{|r|}{ 구 분 } & 실 & 집행액 (백만원) \\
\hline \multicolumn{2}{|r|}{ 연 수 생 초 청 } & 132과정 2,005명 & 11,360 \\
\hline \multicolumn{2}{|r|}{ 전문인력파견 } & 42국 1기구 79명 & 4,026 \\
\hline \multicolumn{2}{|r|}{ 해외봉사단파견 } & 29국 1,674명 (신규 723명) & 33,597 \\
\hline \multicolumn{2}{|r|}{ 물 자 지 원 } & 79국 8기구 & 9,928 \\
\hline \multicolumn{2}{|r|}{ 프 로 젝 트 } & 28국 2기구 46개 사업 & 21,679 \\
\hline \multicolumn{2}{|r|}{ 개 발 조 사 } & 11국 13개 사업 & 5,109 \\
\hline \multicolumn{2}{|r|}{ NGO 지 원 } & 14국 24개 사업 & 1,231 \\
\hline \multirow{4}{*}{$\begin{array}{l}\text { 특 } \\
\text { 별 } \\
\text { 협 } \\
\text { 력 } \\
\text { 사 } \\
\text { 업 }\end{array}$} & 아프간지원 & 프로젝트사후관리 1건, 연수 77 명, 전문가 2명 & 563 \\
\hline & 이라크지원 & 프로젝트 4건, 개발조사 1건, 연수 488명, 전문가 10 명 & 57,322 \\
\hline & 남아시아지원 & 프로젝트 4건, 국제기구지원 9건 & 26,027 \\
\hline & 파키스탄지원 & 프로젝트 1건, 국제기구지원 6건, 구호단 파견 39명 & 3,656 \\
\hline \multicolumn{2}{|r|}{ 협력사업지원 } & $\mathrm{ODA}$ 연구조사, 홍보, 정보화 등 & 7,147 \\
\hline \multicolumn{3}{|r|}{ 계 } & 181,646 \\
\hline
\end{tabular}

※예산집행실적은 2005년도 결산서 기준 


\begin{tabular}{|c|c|c|c|c|}
\hline 구 분 & 계 획(A) & 실 적(B) & 실적율 (A/B) & 비 고 \\
\hline 건수 & $\begin{array}{c}\text { 28국 2기구 } \\
46 ㄱ ㅓ ㄴ ~\end{array}$ & $\begin{array}{c}\text { 28국 2기구 } \\
46 \text { 건 }\end{array}$ & $100 \%$ & \\
\hline
\end{tabular}

\begin{tabular}{|c|c|c|c|c|}
\hline 구 분 & 계 획(A) & 실적(B) & 실적율 (A/B) & 비 고 \\
\hline 과정/인원 & $\begin{array}{l}\text { 133과정 } \\
2,180 \text { 명 }\end{array}$ & $\begin{array}{l}\text { 132과정 } \\
2,005 \text { 명 }\end{array}$ & $92.0 . \%$ & 인원기준 \\
\hline
\end{tabular}

- 117 개국 2,005명을 초청, 2004 년도 1,923 명 대비 $4.3 \%$ 증가

- 한국형원전기술, 과학기술정책, 아세안 개도 국 채권시장 육성, 국제통상 및 $\mathrm{WTO}$ 과정 등 총 132 과정 실시

\section{2) 해외봉사단파견}

\begin{tabular}{|c|c|c|c|c|}
\hline 구 분 & 계 획(A) & 실적(B) & 실적율 (A/B) & 비 고 \\
\hline 계 & $\begin{array}{c}\text { 32국 } \\
\text { 1,661명 } \\
\text { (신규 720) }\end{array}$ & 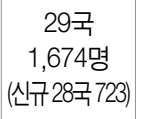 & $100.8 \%$ & $\begin{array}{c}\text { 활동인원 } 1,234 \text { 명, } \\
\text { 귀국 단원 440명 } \\
\text { (연말기준) }\end{array}$ \\
\hline 일반단원 & 31국 1,363 & 29국 1,373 & $102.7 \%$ & (NGO, 행정원 포함) \\
\hline 협력요원 & 23국 264 & 24국 265 & $100.4 \%$ & \\
\hline 협력의사 & 10국 34 & 9국 36 & $100.9 \%$ & \\
\hline
\end{tabular}

- 28국 723 명의 신규 단원을 파견, 목표대비 $101 \%$ 파견

- 남아시아 지진해일 피해 등 긴급재난구호 봉 사단 199 명 활동

- ICT, 농림수산, 보건의료 분야 등 파견 ※이집트(컴퓨터), 인도네시아(미곡생산), 파라과이 (수산양식), 탄자니아간호) 등

\section{3) 프로젝트 · 개발조사}

\section{- 프로젝트}

- 인적자원개발(29.9\%), ICT(11.7\%) 등 우리나 라 비교우위 분야 중점지원 ※과테말라 섬유기술훈련센터 건립, 미얀마 IT개 발 마스터플랜 등

- 보건의료(29.4\%), 환경(11.2\%) 등 범세계적 관심분야 지원

※베트남 산업오염방지, 캄보디아 국립소아병원 현대화 등

\section{- 개발조사}

\begin{tabular}{|c|c|c|c|c|}
\hline 구 분 & 계 획(A) & 실적(B) & 실적율 (A/B) & 비 고 \\
\hline 건수 & 13건 11국 & 13건 11국 & $100 \%$ & \\
\hline \multicolumn{5}{|c|}{ - 산업에너지 분야 집중지원 (44.3\%) } \\
\hline \multirow{2}{*}{\multicolumn{5}{|c|}{$\begin{array}{l}\text { ※베트남 나짱-호치민간 철도복선화 실시설계, } \\
\text { 인도네시아 카리얀 다목적댐 건설 타당성조사, }\end{array}$}} \\
\hline & & & & \\
\hline \multicolumn{5}{|c|}{ 미얀마 송전망 건설 타당성조사 등 } \\
\hline \multicolumn{5}{|c|}{ - 보건의료, $\mathrm{ICT}$ 분야 등 지원 } \\
\hline \multicolumn{5}{|c|}{ 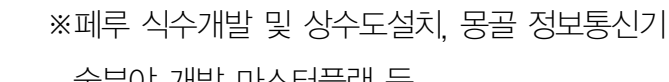 } \\
\hline
\end{tabular}

\section{4) 전문인력파견}

(단위 : 건)

\begin{tabular}{|c|c|c|c|c|c|}
\hline \multicolumn{2}{|c|}{ 구 분 } & 계 획(A) & 실적(B) & 실적율 (A/B) & 비 고 \\
\hline 전문가 & 인원/국 & $\begin{array}{c}\text { 40명 } \\
\text { / 21국 1기구 }\end{array}$ & $\begin{array}{c}\text { 40명 } \\
\text { / 21국 1기구 }\end{array}$ & $100 \%$ & $\begin{array}{l}\text { 계속: } 1 \text { 명 } \\
\text { 신규:39명 }\end{array}$ \\
\hline 의 사 & 인원/국 & 18명 / 18국 & 19명 / 18국 & $105.6 \%$ & 계속:18명 \\
\hline $\begin{array}{l}\text { 태권도 } \\
\text { 사 범 }\end{array}$ & 인원/국 & 20명 / 20국 & 20명 / 20국 & $100 \%$ & 계속:20명 \\
\hline
\end{tabular}


- 인도네시아 증권인프라 구축, 캄보디아 직업 훈련, 에콰도르 중소기업육성, 우크라이나 에너지관리 분야 전문가 등

- 몽골 한의사, 피지 산부인과, 우간다 내과의사 등

- 네팔, 파라과이, 우즈베키스탄, 수단, 남아공 등 태권도협회 파견

\section{5) NGO 지원}

\begin{tabular}{|c|c|c|c|c|}
\hline 구 분 & 계 획(A) & 실적(B) & 실적율 (A/B) & 비 고 \\
\hline 건수 & 14국 24건 & $\begin{array}{l}\text { 14국 24건 } \\
\text { 12.3억원 }\end{array}$ & $100 \%$ & \\
\hline
\end{tabular}

- 전년대비 $17.7 \%$ 의 예산증가로 총 14 국 24 건 지원

※필리핀 결핵퇴치, 몽골 축산시범마을 개발, 방 글라데시 공중보건사업 등

- 개도국 일반주민을 대상으로 한 grassroots 지원

\section{6) 전후재건복구지원}

(1) 이라크재건지원

(단위 : 건, 명, 백만원)

\begin{tabular}{c|c|c|c|c}
\hline 사업명 & 계 획(A) & 실 적(B) & 실적율 (A)B) & 비 고 \\
\hline 계 & 57,500 & 57,322 & $99.7 \%$ & \\
\hline 물자지원 & 27,227 & 27,209 & $99.9 \%$ & \\
\hline 개발조사 & 1건 & 1건 & $100 \%$ & \\
\hline 프로젝트 & 4건 & 4건 & $100 \%$ & \\
\hline 연수생초청 & 47과정 460명 & 48과정 488명 & $106 \%$ & \\
\hline 전문가파견 & 2분야 10명 & 2분야 10명 & $100 \%$ & \\
\hline
\end{tabular}

- 이라크 정부능력강화를 위한 물자지원 집 중지원
- 현지 치안불안, 수원태세 및 행정체계 불 안정 등으로 사업추진에 어려움이 있었음 에도 불구, 아르빌 지역을 중심으로 전년 2 건 대비 4건의 신규 프로젝트 추진 ※아르빌 교통관리시스템 현대화, 시범학교 건립 사업 등

- 연수생초청 및 물자지원은 당초 계획대로 사업추진 완료

(2) 아프간재건지원

- 전후재건 지원사업의 성공적 마무리를 위 하여 연수생초청 및 전문가파견 등 사후관 리 집중지원 (50만불)

- 기지원 프로젝트의 사후관리를 현지 활동 중인 아국 $\mathrm{NGO}$ 를 통해 수행함으로써 사 업간 연계 및 사업효과 지속성 제고 도모

\section{7) 긴급재난복구지원}

\section{(1) 남아시아지원}

- 스리랑카 마하나마 교량개보수, 인니 아체 친선병원건립 등 2 개국 4 개 프로젝트 지원 ※스리랑카 마하나마 교량개보수('05-'07/ 7,000 천불) : 기간시설 복구지원을 통한 경제 회생 및 생계기반 강화

※인니 아체지역 친선병원 건립('O5-'07/3,700 천불) : 지진해일 피해지역 주민에 대한 의료 서비스 개선을 통한 주민 건강증진 등

- 재난발생 직후, 피해현장에 긴급구조대 급 파, 봉사단 파견, 구호물품 전달 등 신속한 
긴급구호 실시

(2) 파키스탄지원

- 텐트, 모포 등 대피시설 및 응급의약품 지 원, 구호인력(39명) 파견

- WFP, UNICEF, WHO 등 국제기구를 통 한 현금지원(457천불)

- 지진발생 직후, 1 일만에 구조팀 및 의료팀 을 구성하여 선발대 우선 파견

- 활동지역 확정 및 피해지역 수요파악 후 본대를 파견하는 등 긴급재난에 대해 신 속·체계적으로 지원

(3) 기 타

- 태풍, 가뭄, 홍수, 기근 등 재난피해에 대 한 긴급지원

※과테말라 허리케인(305천불), 수단 가뭄(100천불), 루마니아 홍수(80천불), 부룬디 기근(50천불) 등

\section{4. 사업결과분석}

\section{가. 중동 및 아시아 중점지원}

- 2005년도 KOICA 무상원조는 2.1억불로 전년 도 1.8 억불 대비 $19.4 \% / 0.3$ 억불 증가 (이하 잠 정실적)

- 지역별 지원비중은 중동 $39.3 \%$, 아시아 $32.5 \%$, 중남미 $5.7 \%$, 아프리카 $5.3 \%$, 동구 CIS $4.4 \%$ 순으로 지원

- 중동지역 점유율이 높은 이유는 이라크 특별 지원에 기인 ※이라크 제외시 아시아 $50.1 \%$, 중남미 $8.6 \%$, 아 프리카 $8.0 \%$, 동구 $6.7 \%$, 중동 $6.4 \%$ 순 - 아시아 지원총액 중 CLMV 4개국에 대한 지 원비중은 $30.1 \%$ 차지

- 중남미 지원비중은 전년대비 소폭( $0.8 \%)$ 증가 했으나, 아프리카 지원비중은 소폭(0.8\%) 감소

〈표1. 2005년도 지역별 지원내역 〉

\begin{tabular}{c|c|c|c|c|c|c|c|c|c}
\hline 지역 & 계 & 아시아 & 중남미 & 동구 & 중동 & 아프리카 & 오세아니아 & 기타 & 국제기구 \\
\hline 지원액 & 215,120 & 69,985 & 12,296 & 9,552 & 84,569 & 11,409 & 811 & 18,190 & 8,310 \\
\hline 비중 & 100.0 & 32.5 & 5.7 & 4.4 & 39.3 & 5.3 & 0.4 & 8.5 & 3.9 \\
\hline
\end{tabular}

〈표2. 2005년도 분야별 지원내역 〉

\begin{tabular}{c|c|c|c|c|c|c|c|c|c|c|c|c|}
\hline \multirow{2}{*}{$\begin{array}{c}\text { 분야 } \\
\text { 계 }\end{array}$} & $\begin{array}{c}\text { 교육 } \\
\text { 훈련 }\end{array}$ & $\begin{array}{c}\text { 보건 } \\
\text { 의료 }\end{array}$ & $\begin{array}{c}\text { 공공 } \\
\text { 행정 }\end{array}$ & ICT & $\begin{array}{c}\text { 산업 } \\
\text { 인프라 }\end{array}$ & $\begin{array}{c}\text { 무역 } \\
\text { 금융 }\end{array}$ & $\begin{array}{c}\text { 농림 } \\
\text { 수산 }\end{array}$ & 그외 & $\begin{array}{c}\text { 행정성 } \\
\text { 경비 }\end{array}$ & $\begin{array}{l}\text { 긴급구호 } \\
\text { /재건지원 }\end{array}$ & $\begin{array}{c}\text { NGO } \\
\text { 지원 }\end{array}$ \\
\hline 지원액 & 215,120 & 36,913 & 44,609 & 28,551 & 17,228 & 19,424 & 937 & 8,541 & 8,549 & 15,766 & 32,590 & 2,011 \\
\hline 비중 & 100.0 & 17.2 & 20.7 & 13.3 & 8.0 & 9.0 & 0.4 & 4.0 & 4.0 & 7.3 & 15.1 & 0.9 \\
\hline
\end{tabular}




\section{나. 보건 및 교육분야 집중지원}

- 2005년도 분야별 지원 비중은 보건의료 $20.7 \%$, 교육 $17.2 \%$, 행정제도 $13.3 \%$, 산업에 너지 $9 \%$, ICT $8 \%$, 농업 $4 \%$ 순

- MDGs 달성을 위한 $\mathrm{BHN}$ 분야 및 $\mathrm{HRD}$ 에 대 한 중점지원

- 개도국의 빈곤 - 소외계층에 대한 의료혜택 및 기초교육 기회 확대 등을 통하여 국제사 회의 MDGs 달성 노력에 동참

※보건의료 및 교육분야 지원비중은 전년대비 각 각 $9.1 \%, 5.5 \%$ 증가

\section{다. 이라크 - 아프간 등 성실한 재건복구 이행}

a 열악한 사업환경에도 불구, 차질없이 사업수행

- 국제사회에서의 우리나라 브랜드가치 제고

- 파병지역인 아르빌을 중심으로 전후재건복 구사업 실시

- 우리군의 안정적인 활동 및 아국 인식제고에 기여

- 치안사정으로 인해 지연됐던 바그다드지역 은 "원격관리에 의한 사업추진" 기반 마련

- 중동지역 특별지원

- 이라크 파병에 대한 중동지역 우호분위기 조 성을 위해 특별지원

- 중동지역 17 개국에 대하여 '04 '05년간 3,600 만불 지원

a 아프간 재건사업 사후관리 강화

- 2005년도 신규예산의 축소에도 불구, 사후 관리를 강화하여 "대아프간 특별협력사업"
을 성공적으로 마무리

\section{라. 신속한 재난구호활동 전개}

- 남아시아 및 파키스탄 재난 발생시, KOICA 구 호대 급파

- 현지 활동 봉사단원 및 귀국 봉사단원, 119 구조대 등

- 재건사업 후속지원

- 남아시아 재난복구 특별사업으로 분류하여 피해지역 재건지원

\section{마. 국민참여형 사업 확대}

a 일반국민 참여확대를 통해 "국민과 함께하는 원조” 실천

- 최근 5 년간 해외봉사단은 6.4 배, $\mathrm{NGO}$ 지원 은 3.6 배 증가

a 특히, 해외봉사단 파견규모는 '91-'04년간 연 간활동인원이 평균 200 명이었으나 '05년도에 는 1,600 여명으로 대폭확대

- 2005년도 한국의 해외봉사단 파견규모는 미국, 일본, 이탈리아, 노르웨이, 영국에 이 어 세계 6 위

※미국(Peace Corps) 7,800여명, 일본(JOCV) 3,600 여명, 이탈리아 3,400여명, 노르웨이 1,600 여명, 영국(VSO) 1,400여명 ('O5년 연간활 동인원 기준)

바. 고객만족도 제고

정부출연기관 중 최상위 평가 
- 연수생 및 수원국 원조총괄기관 등을 대상 으로 한 설문조사 결과

- 수원국 개발수요에 부합하는 사업발굴 및 시행 노력

※설문조사결과 고객만족도 평균 86.9점

\section{III. 평가 및 문제점}

\section{1. 종합평가}

- 2005년도 KOICA 대외무상원조사업은 대 - 내 외적 환경변화에 효과적으로 대처하면서, 국제 사회의 빈곤퇴치 및 국제적 재난에 대한 재건복 구 지원 노력 등에 적극 참여한 것으로 평가됨.

a 그러나, 지원대상 국가 수의 과다 및 국별 중점 지원 분야 미선정 등으로 인하여 한정된 재원 의 효율적 배분 및 성과중심의 사업수행에는 한계가 있었음.

- 사업수단별 투입위주의 지원방식으로 인해 성 과중심적 사업체계가 미비함으로 국가개발계 획의 조화 등 효과적이고 전략적인 원조방법을 모색하는 것이 필요함.

- 이에 따라, 2005년 12월 2006-2009 대외무 상원조사업 추진전략 수립을 통하여 “선택과 집중의 원칙”에 의한 협력대상국 선정기준 및 국별 · 분야별 집행전략을 마련함으로써 무상 협력사업의 전환점을 맞음.

- ODA 규모 증가로 인해 Sector별 Approach
등 원조체제 개선 필요

- 중점협력국 대상 Country Program 수립 및 프로그램형 사업수행체제 개편 필요

\section{2. 문제점}

\section{가. 정책사항}

- 대외원조규모 미흡

- 우리나라의 경제규모에 상응하는 ODA 규모 로 확대 필요 (2005년도 OECD/DAC 회원 국 $\mathrm{ODA} / \mathrm{GNI}$ 평균 $0.33 \%$ - 우리나라 $0.09 \%)$

- 2005년도 우리나라 ODA 규모는 총액 기준 전년대비 $75 \%$ 가 증가되었으나, 이는 IDB 가입 등에 따른 일시적 현상에 기인 ('04년 $0.06 \%)$

- 무상원조 비중 저조

- $\mathrm{OECD} / \mathrm{DAC}$ 회원국 평균 무상비율은 $90 \%$ 를 상회

- 일부국가를 제외한 대다수 공여국들은 $100 \%$ 무상원조 실시

- 국제사회 동향을 고려, 우리나라의 무상비 중 상향조정 필요

※우리나라 중기재정운영계획에 상정된 2009년 도 무상비율은 $45 \%$ 수준

- 투입위주의 원조사업 수행

- 사업수단별 투입위주의 사업으로 성과위주 의 사업수행에 한계

- 중장기전략 부재로 전략적인 원조목표 수립 
과 수원국 맞춤형 사업수행 미흡

- 사업평가 및 사후관리 체제 미흡

- 국별원조정책 미비

- 사업중심 원조로 수원국에 대한 종합적이고 전략적인 원조계획 수립불가

- 지원분야 분산으로 우리의 개발경험 전수 및 지원성과 미흡

- 국별 발전단계에 부합하는 종합적 지원을 위한 사업수단간 연계미흡

- 소액 다국가 지원으로 인한 원조 효과성 저하 - 2005년도 지원 국가 수는 138 개국으로 한 정재원의 효율적 배분에 한계

- 2005년도 지원 상위 10 개국 비중은 전체사 업비의 $70 \%$ 차지, 이를 제외한 $30 \%$ 의 재원 을 128 개국에 분산 지원

〈표3. 2005년도 상위 10대 수원국 〉

(단위 : 백만원, \%)

\begin{tabular}{|c|c|c|c|}
\hline 순위 & 국명 & 지원액 & 점유율 \\
\hline 1 & 이 라 크 & 75,624 & 40.1 \\
\hline 2 & 스 리 랑 카 & 12,576 & 6.7 \\
\hline 3 & 인도네시아 & 9,531 & 5.1 \\
\hline 4 & 베 트 남 & 9,515 & 5.0 \\
\hline 5 & 캄 보 디 아 & 5,954 & 3.2 \\
\hline 6 & 필 리 핀 & 5,182 & 2.8 \\
\hline 7 & 이 집 트 & 4,162 & 2.2 \\
\hline 8 & 미 얀 마 & 3,490 & 1.9 \\
\hline 9 & 아프가니스탄 & 3,393 & 1.8 \\
\hline 10 & 우크라이나 & 3,235 & 1.7 \\
\hline 계 & & 132,664 & 70.3 \\
\hline
\end{tabular}

- 본부위주의 업무체제로 현지실정 반영 미흡

- 일괄적인 수요조사 실시에 따라 수원국의
개발수요 반영 미흡

- 사업수행 현장에 있는 재외공관 및 해외사 무소 역할강화 필요

- 수원국의 Ownership제고 및 현지실정에 맞

는 사업발굴 미흡

- 공급자의 일방적인 지원을 방지하기 위해 수원국과 협의체제 강화 필요

- 무상원조사업 수행주체 분산으로 사업효율 성 저하

- 정부의 무상협력사업 정책적 일관성 및 사 업추진 효율성 저하 우려

※최근 5년간 우리나라 전체 무상원조중 타부처 비중은 약 $17 \%$ 를 차지

- 사업수행주체의 분산은 수원국에서 우리나 라 원조정책 혼란 야기

- KOICA는 우리나라 대외무상원조 전담을 위해 설립

\section{나. 사업부문}

1) 연수생초청

a 개발경험 소개 위주의 연수로 편중

- 개발경험 소개만으로는 개도국 근본문제 해 결에 한계

- 개도국 수요가 많은 Governance 부분은 대 부분 정책소개에 국한

- 정책소개위주에서 정책개발위주의 맞춤형 연수로 개선 필요

※ 정책.기술소개형 연수 $65 \%$, 기술습득형 연수 $26 \%$, 시찰형 연수 $6 \%$ 차지, 정책개발형 연수는 부족 
- 공급자 위주의 단순 연수형태 지양 필요

- 연수형태가 초청연수로 일원화되어 있어 개 도국의 다양한 수요에 부응하는데 한계

- 타 공여국과 같이 연수형태의 다양화 필요 ※ 이집트, 튀니지, 모로코, 태국 등은 지역성을 고려한 현지 연수 요청

아프리카 최빈국의 경우 연수효과 제고를 위 해, 현지연수, 제3국연수 필요

a 사업계획수립절차 복잡

- 개도국 수요조사, 국내부처 수요조사, 연수 기관 모집제안서 공모 등이 동시다발적으로 이루어져 사업계획수립에 애로

- 연수기관과의 단년계약으로 업무예측성이 낮고, 유기적인 업무 협조관계도 미흡

- 매년 국별수요조사를 통해 사업이 결정되므 로, 중장기전략 부재

a 연수기획 · 평가 능력 미흡

- 수원국 실정에 적합한 연수과정 개발 부족 ※시간이 많이 투입되는 행정, 회계, 행사, 산업시 찰 업무에 집중

- KOICA 인력사정상 매년 증가되는 연수인 원에 대한 지원에 한계

- 맞춤형 국별과정은 증가하고 있는 반면, 내 용충실도는 다소 미흡

- 일반인 참여 프로그램 부족

- 연수사업은 국내사업으로 민간 참여기회는 많은 편이나, 일반 국민들이 참여하는 프로 그램은 제한적

※Home Visiting은 연수기관 위주로 운영되어 민박 프로그램 활성화 미흡
- 연수기관의 주인의식 및 참여의지 결여

- 단순한 연수위탁 관계에서는 주인의식, 참여 의지가 부족하여 효율적인 사업수행에 한계 - 최근 공공기관, 지방자치단체 등의 국제개 발협력사업 관심증대

- 유사 프로그램을 타 관련부처에서 주도적으 로 운영하는 사례증가 ※교육부, 정통부, 보건복지부, 과기부, 환경부, 여 성부 등

\section{2) 해외봉사단파견}

- 적격자원 확보 애로

- 농림수산, 이공계 등 전문분야는 적격자원 이 부족하고, 중도포기자도 다수발생

- 2005년 지원자는 4,134명으로 모집공고 인원 946 명 대비 4.4 배가 지원하였으나, 지원자중 실제 응시자수는 지원자의 $24.3 \%$ 에 불과

- 최종 합격인원은 492 명이었으나, 합격자의 $21.5 \%$ 가 중도포기

- 개도국 수요가 가장 많은 농업분야는 모집 인원의 $29 \%$ 수준인 47 명지원

〈표4, 2005년도 해외봉사단 모집.선발현황 〉

(단위 : 백만원, \%)

\begin{tabular}{c|c|c|c|c|c|c}
\hline \multirow{2}{*}{ 구 분 } & $\begin{array}{c}\text { 모집공고 } \\
(\mathrm{A})\end{array}$ & $\begin{array}{c}\text { 지원인원 } \\
(\mathrm{B})\end{array}$ & $\begin{array}{c}\text { 서류합격 } \\
(\mathrm{C})\end{array}$ & $\begin{array}{c}\text { 응시인원 } \\
\text { (D) }\end{array}$ & $\begin{array}{c}\text { 합격인원 } \\
(\mathrm{E})\end{array}$ & $\begin{array}{c}\text { 출국인원 } \\
(\mathrm{F})\end{array}$ \\
\hline \multirow{2}{*}{ 인원(명) } & 946 & 4,134 & 2,128 & 1,005 & 492 & 386 \\
\hline \multirow{2}{*}{ 비율(\%) } & - & 436.9 & 51.5 & 24.3 & 11.9 & 9.3 \\
\cline { 2 - 7 } & - & $\mathrm{B} / \mathrm{A}$ & $\mathrm{C} / \mathrm{B}$ & $\mathrm{D} / \mathrm{B}$ & $\mathrm{E} / \mathrm{B}$ & $\mathrm{F} / \mathrm{B}$ \\
\hline
\end{tabular}

※국제협력요원, 국제협력의사, NGO, 산 · 학협력대학 파견 등 제외 
〈표5. 2005년도 해외봉사단 분야별 모집 · 응시자 현황 〉

(단위 : 백만원)

\begin{tabular}{|c|c|c|c|c|c|c|c|c|c|c|c|c|c|c|c|c|c|c|}
\hline \multirow{3}{*}{ 구분 } & \multicolumn{3}{|c|}{ 계 } & \multicolumn{3}{|c|}{ 교육훈련 } & \multicolumn{3}{|c|}{ 농림수산 } & \multicolumn{3}{|c|}{ 산업인프라 } & \multicolumn{3}{|c|}{ 의료보건 } & \multicolumn{3}{|c|}{ 정보통신 } \\
\hline & \multicolumn{2}{|c|}{ 모집 } & \multirow{2}{*}{\begin{tabular}{|l|} 
응시 \\
인원 \\
\end{tabular}} & \multicolumn{2}{|c|}{ 모집 } & \multirow{2}{*}{$\begin{array}{l}\text { 응시 } \\
\text { 인원 }\end{array}$} & \multicolumn{2}{|c|}{ 모집 } & \multirow{2}{*}{$\begin{array}{l}\text { 응시 } \\
\text { 인원 }\end{array}$} & \multicolumn{2}{|c|}{ 모집 } & \multirow{2}{*}{$\begin{array}{l}\text { 응시 } \\
\text { 인원 }\end{array}$} & \multicolumn{2}{|c|}{ 모집 } & \multirow{2}{*}{\begin{tabular}{|l|} 
응시 \\
인원 \\
\end{tabular}} & \multicolumn{2}{|c|}{ 모집 } & \multirow{2}{*}{$\begin{array}{l}\text { 응시 } \\
\text { 인원 }\end{array}$} \\
\hline & 직종 & 인원 & & 직종 & 인원 & & 직종 & 인원 & & 직종 & 인원 & & 직종 & 인원 & & 직종 & 인원 & \\
\hline 계 & 110 & 946 & 1,005 & 29 & 246 & 351 & 29 & 162 & 47 & 30 & 161 & 126 & 15 & 157 & 218 & 7 & 220 & 263 \\
\hline 초과 & 25 & 493 & 822 & 9 & 100 & 281 & & & & 4 & 33 & 66 & 7 & 143 & 213 & 5 & 217 & 262 \\
\hline 동수 & 14 & 64 & 64 & 5 & 51 & 51 & 5 & 5 & 5 & 3 & 5 & 5 & 1 & 3 & 3 & & & \\
\hline 미달 & 32 & 311 & 119 & 6 & 77 & 19 & 12 & 131 & 42 & 11 & 96 & 55 & 2 & 5 & 2 & 1 & 2 & 1 \\
\hline 없음 & 39 & 78 & 0 & 9 & 18 & 0 & 12 & 26 & 0 & 12 & 27 & 0 & 5 & 6 & 0 & 1 & 1 & 0 \\
\hline
\end{tabular}

a 양적확대에 따른 업무시스템화 미흡

- 파견형태의 다양화, 민간부문과의 연계 등 질적수준 제고를 위한 제도적 뒷받침 미흡

- 파견규모 확대에 따른 업무의 전문화 - 체계 화 미흡

a 안전사고 및 의료사고 발생 가능성 증대

- 연간 활동인원인 1,000 명을 넘어섬에 따라 파견단원에 대한 안전 및 의료사고 발생 증가 ※파견인원이 급증한 2004년 이후 사고 및 후송 건수는 2003년 대비 2배 이상 증가

- 사전예방 및 사고신속대응체제 정비 등 안 전관리시스템 구축필요

\section{3) 프로젝트 - 개발조사}

a 국내 개도국 개발 컨설팅 기관 부족

- 국제적 수준의 실무경험과 전문지식을 보유 한 전문가나 기관이 부족하고 이를 효과적 으로 활용할 수 있는 제도적 장치도 부재

- 국내에는 선진공여국과 달리, 개도국 개발 컨설팅에 경험이 있는 전문그룹이 절대 부
족하여 사업수행기관 확보에 애로

- 효과적인 사후관리 제도화 미흡

- 건축, 기자재가 투입되는 개발사업의 경우

사후관리 요소 빈발

- 지원 초기단계에서부터 사후관리를 염두에 둔 중장기적 개발사업 지원전략 및 사후관 리의 제도개선 필요

- 개도국 개발과제의 종합적인 지원체제 미흡 -「분야별 종합지원방식 (Sector-Wide Approaches)」의 도입 필요

- 개도국의 개발문제를 다양한 관점에서 분석 하고, 자원과 기술을 종합적이고 유기적으 로 연계

- 사업추진절차 개선필요

- 신규사업 선정후 사업개시 당해연도에 사전 조사를 실시함에 따라 사업추진 지연 및 사 업선정의 충실도 저해 우려

- 협의의사록 체결후 구상서 교환 지연으로 인해 사업추진 지연 
4) 전문인력파견

a 전문가 참여인력 부족

- 일부 분야를 제외하고는 대부분 유관기관의 현직자에 의존

- 제한된 가용인원으로 파견전문가의 역량 부 족 현상 발생

- 전문가 Pool 제도를 운영하고 있으나, 등록 자원의 활용실적 저조

※ 2005년도의 경우 40명 파견 중 3명이 Pool 등록자원

- 전문가 활동성과 활용 미진

- 활동성과 및 결과물이 내부자료로 활용되는 데 그치는 등 활동성과의 대외활용도 미진

5) NGO 지원

- 지원규모 영세

- 특별협력사업 제외시 NGO 예산은 매년 소 폭 증액

※ 최근 5년간 연 평균 9.8\% 증

- 1 개사업 지원규모는 평균 5 천만원 내외로, 성과달성에 미흡

※ 지원총액 대비 지원사업수를 고려, 불가피하게 1 개사업당 지원상한액 설정

- 단년도 지원으로 사업의 연속성 부족

- 통상 $\mathrm{NGO}$ 들은 중장기적으로 사업을 실시 하고 있으나, $\mathrm{KOICA}$ 는 1년 단위로 사업을 선정 · 지원하고 있어 사업연속성 결여

- NGO 등록제도 활용성과 미흡

- 기존 등록제도는 우수단체 검증 실효성이 낮은 반면, 이를 유지하기 위한 행정력 소요
과다 등 문제점 발생

- 미등록 NGO단체들의 불만제기 가능성 내재

6) 전후재건복구지원 (이라크 · 아프간)

- 종합적 사후관리 계획의 부재

- 사업종료후 수원국 능력부족 등으로 효과의 지속성 확보 애로 예상

- 기 지원사업에 대한 효과적인 사후관리를 통해 지속가능발전 기반 마련 필요

- 치안사정 악화

- 파견인력 및 지원물자 테러대상 가능

※ 이라크내 치안부재를 악용한 바그다드대학 및 18 개 국립대 IT인프라 구축사업의 기자재 탈취사건 발생('05.9)

- 치안사정이 개선되지 않아 사업추진에 애로 발생

\section{7) 긴급재난복구지원}

- 해외재난 긴급구호시스템 구축 미흡

- 신속대응을 위한 관계기관 협정체결 등 제 도마련에도 불구, 타 공여국에 비해 긴급재 난 예산 및 인력부족 등 해결과제 산재

- 신속한 지원을 위한 법적 - 제도적 지원부족

- 해외긴급재난구호에 관한 법률 미제정

- 신속한 지원을 위한 사전 구호물자 확보 및 관계기관간 합동훈련 등 제도적 장치 미흡

8) 다자협력

다자지원의 효과성 및 $\mathrm{KOICA}$ 역할정립 미흡 
- 2005년도 다자지원액은 KOICA 사업비의 4\%를 차지, '91-'05년간 평균 지원비중 $3.11 \%$ 보다 높은 수준이나 이는 남아시아 지 진해일 피해지원액의 급증에 기인

- 현행 $\mathrm{KOICA}$ 의 다자지원은 대부분 외교부 의 정책결정 사항에 대한 단순 집행, 단순 Funding 으로 인식

- 국제동향 파악 미흡

- 선진공여국에 비해 다자지원에 대한 중장기 framework나 전략 부재

- MDGs 및 빈곤감소 등 국제적 이슈와 연계 미흡

a 평가 및 사후관리 부재

- 대부분 국제기구에 대한 현금 및 물자공여 지원으로 사업이 종결되어, 지원 성과측정 에 한계

9) 홍 보

- $\mathrm{ODA}$ 의 국민적 인지도 미흡

- 대외원조 중요성과 국제적 역할에 대한 이 해 부족

※ 우리정부의 대외원조 제공사실에 대한 인지도 37\% ('05.8월, 국무조정실 여론조사)

- 대국민 홍보수단 다양성 부족

- 계층별, 대상별 홍보수단의 차별화 및 다양 화 미흡

- 주로 언론매체를 통한 뉴스성 홍보로 $\mathrm{KOICA}$ 기관인식 부족

- ODA 홍보 네트워크 구축 미흡
- ODA 관련 부처 및 기관간 연계강화

- 타 공여국과 같이 현장-본국간의 홍보 네트 워크 구축 필요

$\mathrm{IV}$. 개선조치사항

\section{1. 기조치사항중 정책부분}

\section{가. 대외무상원조사업 추진전략 수립 ('05.12)}

1) 수립배경

- 국내외 $\mathrm{ODA}$ 환경변화에 능동적 대처

- 세계적인 ODA 정책방향 변화추세, 우리정 부의 ODA 확대방침, 국내민간부분의 ODA 관심증대 등

- 정부의 '05.11월 ODA 개선종합대책 관련, 무상원조 실천전략 수립

2) 전략목표 및 기본방향 수립

- 중기무상원조정책 및 국가별원조정책 수립

a 전략적 우선순위에 따른 협력대상국 선정

- 한국형 원조모델발전

- 국민참여형 원조추진

- 현장중심의 사업수행체제 구축

- 사업수행 역량강화

- 평가 및 사후관리 강화

- 해외긴급재난구호 체제 구축 
3) 소액다국가 지원방식 개선

- "선택과 집중” 원칙에 따라 한정된 재원의 효율 적 배분 실현

- 2006년도 협력대상국을 127 개국에서 58 국' 으로 대폭 축소

\section{4) 사업집행전략 수립}

- 지역별 · 국별, 분야별 - 사업별 상세 사업수행 전략 수립

\section{나. 무상원조사업 수행체계 개선}

1) 중점 및 일반협력국에 전략적 집중지원

- 개발원조 성과제고와 재원배분 효율성을 고려, 선별 지원

- 중점협력국과 일반협력국으로 구분 ※ 협력대상국 선정 고려요인

: (1) 수원국 빈곤상황, (2) 수원국 통치상황 (Governance), (3) 우리나라와의 외교적관계, (4) 경제개발잠재력, (5) 우리나라의 경협관계 등

2) 국별원조정책 (Country Program/ CP) 수립

- 전략적이고 연속성이 있는 개발원조 실현을 위 해 국별계획 수립

- 수원국 빈곤감소전략 (PRSP), 천년개발목 표 $(\mathrm{MDGs})$ 와 원조방향을 일치시켜 수원국 경제개발계획상의 고리와 연계성 강화

- 사업중심에서 국가중심으로 전환

- 국별전략 뿐만 아니라 지역전략 (Regional Strategy)도 수립

\section{3) 지원분야 집중}

- 비교우위 분야를 중심으로 전략적 지원분야 선정

- 수원국의 국가개발계획 및 우리의 비교 우위를 고려

- KOICA 중점지원 분야 결정 ('06. 5)

(1) 교육(Education), (2) 보건의료(Health),

(3) 행정제도(Governance), (4) 농촌개발 (Rural Development), (5) 정보통신(ICT), (6) 산업에너지(Industry \& Energy), (7) 환경 및 기타(Environmental \& others), 8) 재난 구호(Disaster Relief \& Reconstruction)

4) 정책대화 강화

- 국별 원조정책과 수원국의 개발계획과의 조화 를 통해 원조효과성 제고

- 공관과 수원국간의 협의채널을 강화하고 정 책대화를 활성화

- 수원국과의 원조조율 및 정책일관성 유지

- 정확한 개발수요 및 실천방안 협의

\section{다. 사업수행방식의 대 전환}

1) 프로그램 체제로 전환 (우리나라 ODA의 新모델)

- 국제원조 패턴을 고려하되, 우리 실정에 맞는 선진원조 기법 개발

- 지원규모가 적고, Sector별 Approach 기반 이 미조성되었던 과거와 달리, 무상원조규 모가 증가하므로 미래지향적 체제로 체질 개선 필요 
- 한 차원 높은 개발원조 실현을 위해서는, 정 책적이고, 전략적인 사업수행체제로 개편 ※ 성과위주로 지원하되, 그 목표를 보다 소프트 웨어화

ם「단위사업별로 사업이 종료되는 현 원조시스 템」을「국별개발과제를 종합지원하는 프로그 램식으로 전환」하여 하기 현안문제 해소

- 개도국의 근본적인 문제해결을 위한 전략적 원조계획수립이 어렵고,

- 지속발전 가능한 원조방향 설정에도 한계

- 사업별 목표가 뚜렷치 않아 정확한 평가에 애로, 평가결과 Feedback도 미미

- 한국형 원조모델을 효과적으로 적용 - 발전 시키는데 한계

- 목표중심적, 종합개발형 원조체제 구축

- 국별원조정책과 정책대화를 강화하여 원조 의 질적제고 달성

※ 각 국별지원전략 범위 내에서 개발목표 설정 후, 목표에 합당한 중점지원분야를 선별해서, 세부적인 이슈를 정하고, 동 개발이슈에 필요 한 각종 사업수단을 투입하여 당초 계획한 목 표 달성

- 개발원조와 개도국 국가개발계획과의 일관성 유지

- 개도국 빈곤감소전략, 천년개발목표 등 국 가개발계획과 직접 관련이 있는 개발목표를 설정하여 개도국과 함께 이를 달성하는 체 제로 전환

※ 예) 과거에는 병원건립이 사업목표였으나, 앞 으로는 유아사망율감소, AIDS 예방등이 사업
목표가 되고 병원건립은 수단의 일부가 됨.

\section{2) $\mathrm{KOICA}$ 조직의 선진화}

- “프로그램 방식 원조체제” 및 “우리 경제개 발경험전수”를 보다 효과적으로 수행가능하 도록 조직정비

- 국가와 분야집중을 강조한 전략적인 사업수 행체제 구축

- 지역정책기능 강화

- 현 지역정책팀을 지역정책부로 확대 개편 (3개팀 신설)

※ 중장기 원조정책 수립, 협력대상국 선정 및 지 원분야 선정, 국별 원조전략(CP) 수립, 연도별 사업계획 수립 등 기능 수행

- 수원국 정부와의 정책대화 및 원조정책수립

- 중점지원분야에 입각한 사업수행 편제

- 국제협력단의 중점지원 8개 분야 반영

※ 교육훈련팀, 행정제도팀, 보건의료팀, 글로벌이 슈팀, 정보통신팀, 산업에너지팀, 농촌개발팀, 재난복구팀

- 「전략수립, 사업수행, 평가」의 유기적인 삼각 균형 유지

- 지역부서, 사업부서, 평가부서간의 효과적 인 조율을 위해 임원의 관장업무를 탄력적 으로 운영

- 평가업무의 강화차원에서 사업평가팀을 '사 업평가실 로 격상

- 행정 및 지원부서 슬림화

- 원조기획 및 사업발굴을 강화하기 위해, 총 무부·기획부를 '기획관리부’ 로 통합 


\section{라. 해외재난구호 시스템 구축}

1) 선진형 재난구호체계로 전환

- 현금지원에서 구호활동으로 지원체계 개선

- 과거 현금지원 위주의 재난구호에서 긴급구

호대파견, 긴급물자 수송 등 직접 구호활동

에 참여하는 선진원조형태로 전환

- 좀 더 안정적이고 체계적인 재난구호활동을

위해 법적, 예산적 장치 마련중

※ ‘해외긴급구호에 관한 법률(안)' '상임위 상정 . 심의중

※'07년부터 해외재난 긴급구호예산을 현 300 만불 규모에서 1,000 만불규모로 증액 검토중

\section{2) $\mathrm{KOICA}$ 긴급구호대 결성}

- 항시 파견체계 구축 등 신속한 대응체계 마련

- 재난초기, 신속한 지원을 위해 전문기관과

범국가적 협력체제 구축

- 파견절차 및 행동요령 등 필요한 매뉴얼 작성

- 구호대 모의훈련 등 실시

\section{〈긴급구호대 구성〉}

※ 긴급구조반 : 소방방재청, 119 구급대,

$$
\text { 한국구조연합회 }
$$

※ 의료지원반 : 서울대병원, 국민건강보험공단

※ 긴급구호 봉사단 : 민간단체

'06. 5월 인니 족자카르타 지진발생후 22시간만 에 KOICA 구호대 및 의약품을 현장에 파견 (해외 구호대로서는 최단시간내 지원한 국가 중 하나)

\section{3) 긴급구호후 재건복구사업 후속지원}

a 필요시 피해지역에 대한 재건지원을 중장기적
으로 지원

- 사회기능 정상화를 위한 인프라재건 및 역 량강화 중점지원

- 지원효과의 지속성 확보를 위한 사후관리계 획 수립

\section{2. 기조치사항중 사업부분}

\section{가. 연수생초청}

- 연수과정의 차별화 및 전문화

- 연수과정을 연수목적 및 내용에 따라 4개 과 정으로 大분류

(1) 기본과정(개발정책, 기능 - 기술) (2) 특별 과정(외교적 수요) (3) 국별과정(3년 중기) (4)공동연수

- 연수기간 적정운영 및 장기연수과정 개선 - 과정의 목적에 따라 기간을 점차 확대·운영 ※ 기본과정은 2주미만 단기연수 폐지

-'05.11월, 장기연수 기본방향을 정립 ※ 2006년도에는 중점협력국 중심으로 3-4개 장기과정을 특화, 연수기관은 공모

a 절차간소화 및 전산화 (Out-sourcing 확대) - 과정운영은 연수기관, 연수지원은 위탁업체 에 대폭이관 ※ 사업담당자의 사업기획 · 평가 능력배양 Project Design Matrix, Project Management Professional 등 사업기획 및 관리 교육 실시

- 새로운 연수형태 개발 (현지연수)

- 현지연수 타당성검토를 위한 연수기관 및 
수원기관 자문

- 해외사무소를 통해 현지연수 가능 확인, 구 체일정 등 준비

※ 2006년도 새마을운동, IT교육 등 3개 과정 시범실시

a 연수과정 종료평가 개선

- 객관적이고 성과중심의 평가가 가능하도록 종료평가 양식 개선

- 통합평가 체제로 전환키 위해 연수생 설문 지 평가방법의 전면 재검토중

- 연수과정 심의 강화

- 상반기 종료 37 개 과정의 타당성, 향후 과정 지속 여부 등 검토

- 존속과정, 프로그램화 필요과정, 대체 또는 폐지과정 등 심의

\section{나. 해외봉사단 파견}

- 시니어봉사단 제도 도입

- 중장년층 퇴직인력 및 은퇴인력의 경험과 기술 적극활용

- 연령제한 철폐 ※ 40세 이상 관련분야 기술, 지식 및 5년이상 경험, 전문가급

- 단원 안전관리 강화

- 안전 및 의료관리 체계강화를 통해 사고예 방에 중점

※ 해외안전관리(KOV Security Manual) 교육 등

- $\mathrm{KOICA}$ 해외봉사단 종합상황실 및 비상연 락체계 운영
- 긴급후송시스템(SOS Medical Service) 운 영 등

- 봉사단원 진로 및 취업지원

- UNV 파견을 통해 귀국단원 진로개척 및 전 문가로의 인재양성 도모 (KOICA-UNV 기 관간 협정 체결)

- 인터넷 취업전문업체와 계약, 별도의 취업 정보 $\mathrm{KOICA}$ 웹사이트 구축

- 경력관리시스템(Career Path System) 도입

- 해외봉사단 자격인증제 개선

- 선발 단원중 국내훈련 이수자에게만 '봉사 단 자격인증 부여

- 봉사단 자격인증 요건강화로 우수자원 파견 도모

- 기술훈련 인턴쉽 제도 도입

- 팀제봉사단 파견전 농축산, 임업 등 관련분 야 직무교육후 파견

- 국내관련기관 위탁교육을 통해 봉사단 실무 능력 배양

- 해외봉사단 파견업무 프로세스 표준화

- 파견인력의 모집, 교육, 파견, 사후관리까지 One-stop 시스템 구축

\section{다. 프로젝트 - 개발조사}

- 관련규정 제 · 개정

- 프로젝트 및 개발조사사업의 일원화, 용역 계약 세부내용 보완

- 현지조사 경비지급기준 명확화 
- 사업선정위 운영기준 신설 등 효율적 사업 수행기반 마련

- 분야별 사업추진 체제 구축

- 직제개편을 통하여 사업수행분야를 5 개로 대분류

※ 공공행정·제도, 교육훈련, 산업환경, 정보통 신, 의료보건

- 특정 개발이슈에 대해 적극적으로 대응하 고, 이의 해결을 위해 다양한 협력수단을 복 합적으로 활용

※ 개발조사, 프로젝트, 전문가파견을 분야별로 통합

- 선진국 사례조사와 우리사업 특성을 고려, 분야별 사업 추진방향 연구 실시

※「개발사업 분야별 추진방향 」 발간('05.5)

행정제도, 농림수산, 에너지, 환경, 정보통신, 교육훈련, 의료보건 등 7 개분야

a 종료사업 데이터베이스 구축

- 프로젝트 및 개발조사 종료사업의 각종 사 업수행정보를 체계적으로 종합정리

- 정보접근 용이성 및 업무활용도 제고를 위 해 $\mathrm{DB}$ 구축

※'06년 2월부터 용역 착수

a 유관기관과 업무개선 협의체제 구축

- 사업발굴, 계약, 용역수행 등 업무관련 유관 업체와 대화 실시

- 유관기관 제안사항을 반영하여 규정개정, 업무 절차개선 등 검토

\section{라. 전문인력파견}

- 전문가 경비지급기준 개선

- 전문가 경비지급기준 현실화를 통해 우수 적격전문가 선발 도모

- 전문가 국내수당 신설, 전문가 현지활동 지 원강화 등

— 전문가 활동결과 활용 강화방안 마련

- 성과사례 발굴, 파견국의 활동분야에 대한 조사연구 강화

- 홈페이지 게시, 단내외 해당분야 정기간행 물 게재 등 우수자료 공유체계 강화

- 파견전 사전조사 강화

- 수원국과 전문가 파견 활동계획서 및 체크 리스트 사전협의 실시

-6 개월 이상 장기파견은 전문가 파견전 활동 기관 및 직무 현지조사

\section{마. NGO 지원}

a 한국 $\mathrm{NGO}$ 해외봉사단 신설

- 해외원조단체협의회와 위탁용역계약 형태 로 지원

- 2006년도에 처음으로 시도 (13억 지원, 77 명 파견)

a NGO 등록제도 개선 - 국민참여형 사업확대 차원에서 등록제를 신 고제로 전환하여 "NGO Pool" 운영

- 역량있는 $\mathrm{NGO}$ 와 우수사업에 지원이 집중 되도록 심사기준 등 개선

- NGO 업무역량강화 
- 해외원조단체협의회 개발 NGO 대상 교육 프로그램 지원

- 워크샵, 현장방문 등 NGO 역량강화를 위한 다각적 사업추진

※ KOICA, 국제기구 및 타국 NGO 사업현장 방 문교육 실시(9개단체 참가)

\section{바. 전후재건지원 (이라크 · 아프간)}

- 치안불안을 극복하는 특별 사업관리기법 발 굴 · 시행

- 협력사업 수행인력에 대한 신변안전지침 수립

- 사업별로 사업수행체계를 탄력적으로 운영

- KOICA 해외사무소를 통해 차질없이 업무 를 수행하고 생생한 현지실정을 반영

※ KOICA는 아프간 및 이라크 전쟁종료 직후 신 속하게 현지에 사무소를 개설하여 아국 공관 개설 및 타공여국 사무소 설치보다 앞서 사업 추진기반을 마련

(아프간 2001.12.22 종전, 사무소설치는 2002.3.7 / 이라크 2003.5.1 종전, 사무소설치는 2003.5.9 )

- 성공적인 재건복구 이행으로 국제적 위상 제고 - 열악한 현지실정에도 국제사회와 약속한 재 건복구사업을 성실히 수행

- 파병지역인 아르빌 지역을 중심으로 전후재 건복구사업 실시

- 치안사정으로 인해 지연됐던 바그다드지역 은 "원격관리에 의한 사업추진" 기반 마련

- 대 이라크 재건 프로젝트 본격착수

- 2004년까지 단기효과 (Quick Impact) 사업
위주로 진행

- 2005년부터 장기적인 재건효과를 위한 프 로젝트사업 본격 착수

- 어려운 현지여건에도 불구, 차질없이 사업 수행 중

\section{3. 향후 추진과제}

\section{가. 주요 정책과제}

1) ODA 규모 확대

- 우리 경제규모와 국제적 위상에 비해 대외원 조규모 미흡

- 2005년 우리나라 대외원조 규모는 7.4억불 로 GNI 대비 $0.09 \%$, 전년 대비 $75.7 \%$ 증가 - 이는 IDB 가입 등에 따른 국제기구 출자 .

출연에 기인 (2억불)

※ 동 출연금 제외시 ODA/GNI 비율은 $0.07 \%$ 수준으로 2005년도 OECD/DAC 회원국의 ODA/GN| 비율 평균 0.33\%의 $1 / 4$ 수준에 불과

- 국가정책차원에서 ODA 확대목표 연도 및 규 모 조정필요

-'05년 11월, '국제개발협력 개선 종합대책' 에서 제시한 정부의 당초 목표의 의미 퇴색 (2009년 0.1\%/2015년 0.25\%)

$\mathrm{OECD/DAC}$ 회원국의 ODA 증액추세를 고려, 우리나라의 GNI 대비 ODA 비율 달성목표 재 검토 필요

2) 무상원조 비중 확대 
- $\mathrm{OECD}$ 회원국은 무상원조 중심으로 $\mathrm{ODA}$ 실시

- 유상원조는 일본, 스페인 등 일부국가만 실시

- $\mathrm{OECD} / \mathrm{DAC}$ 가입을 앞두고 국제기준에 부 합하는 원조구조 필요

- 무상비율을 선진국 수준인 $90 \%$ 수준으로 조정 필요

※ DAC 권고사항 : ODA 양허율 $86 \%$, 언타이드 화, 최빈국에는 무상원조 제공

\section{3) 정부 무상원조사업 통합}

- 여러부처가 중복 실시하고 있는 무상원조사업 $\mathrm{KOICA}$ 일원화

-「작은정부, 국고의 효율적 집행」에 배치

- 정통부 : '정보통신격차해소에 관한 법률 ('03.1월') 을 제정, 인터넷봉사단 파견, IT연수생초청사업 실시

- 복지부 :'03.12월 설립한 국제보건의료발 전재단 법제화를 골자로 한 한국 보건의료재단법' 제정( 05.12월), 보건의료지원사업 실시

- 문광부 : 문화봉사단파견사업 실시

- $\mathrm{OECD}$ 회원국 같이 무상원조는 전담기관에서 수행하는 것이 타당

- 미국 USAID, 일본 JICA, 캐나다 CIDA, 스 페인 AECI 등

- $\mathrm{ODA}$ 는 개도국과 선진국의 부처간 교류가 아니고, 개발원조라는 국제적 과제를 실천 하는 것으로서, 각 국가들은 공여기관을 설 립하여 전담 수행

\section{나. 평가시스템 강화}

\section{1) 평가범위의 확대}

- 성과관리 자율평가 정착

- 모든 개발협력 프로그램에 대한 사전, 중간, 종료평가 실시

- 사후평가 범위확대

- 국별, 주제별, 이슈별 평가 등 다양하고 종 합적인 평가 수행

- 무상원조사업 전반에 대한 공동평가 실시

\section{2) 평가품질의 향상}

- 평가체제 재구축 및 피드백 강화

- 평가규정 제정 및 우수사례(Best Practice) 피드백 강화

- 평가결과와 조직 성과관리와의 연계

- 평가 가이드라인 재조정

- 평가방법의 개발 및 직원평가역량 강화

- 평가지침 및 평가매뉴얼 개정

- 직원대상 평가교육 실시 및 평가전문인력 양성

3) 평가의 신뢰성 확보

- 제 3 자 평가 확대

- 평가위원회 및 평가수행시 NGO 등 민간참 여 강화

- 성과평가결과 검토 및 사후평가를 위한 평가자문단 설치

- 타 공여국 및 수원국과의 공동평가 실시 
평가결과의 공개 확대

- 홈페이지를 통한 평가결과 적시공개

- 평가연차보고서 발간을 통한 평가결과 체계화

- 영문보고서를 통해 수원국에 평가결과 통보

- 우수사례를 중심으로 대국민 홍보 강화

\section{다. 한국형 원조모델 발전}

1) 우리만의 특화된 모델개발 및 발전

- $\mathrm{OECD}$ 공여국 중 유일한 빈곤극복국가 장점 활용

- 빈곤퇴치국 (Poverty Cutter)의 국제적 명 성을 유용하게 활용

- 대다수 개도국은 우리나라의 개발경험을 전 수 받기를 희망

- 개도국은 개발원조 파트너로서 선진국보다 오히려 우리나라에 기대감 표명

ם 구체적인 개발과제와 기법 발굴

- 선진공여국과 차별화된 원조기법 연구

- 특별 프로그램을 개발 (분야별 원조상품개발)

- 개도국이 우리나라를 발전모델로 인식하고 있는 점을 충분히 고려,

- 한국형 정책 프로그램 제시

※ 우리의 경제개발5개년계획, 새마을운동, 가족 계획, 중소기업육성, 수출촉진, ICT발전, 기술 인력양성, 공기업발전 등

\section{2) 모델개발 연구강화}

- 우리나라 개발경험 연구 및 자료화

- 우리나라 경제개발경험에 대한 국내연구미흡
- 대개도국 전수를 위해서는 한국 개발경험 자료화 필요

- 한국형 개발협력모델의 단계적 확대를 위한 기법연구

※ 타 공여국의 경우에도 자국의 행정경험 및 경 제발전경험 전수를 목적으로 한 - 산하기관 설 치운영 (일본 JICA 국제협력종합연수소 등)

\section{라. 사업별 개선과제}

\section{1) 연수생초청}

- 정책개발 역량강화 중점지원

- 국가별 개발과제를 고려한 국별과정 확대

- 중점지원분야를 선정하여 지속발전 가능토 록 지원

- 사전조사, 정책협의, 워크샵 등 기초조사 강화 ※ 2004년 이후 수원국 맞춤형 국별연수 점차 확대 중

$: 12.3 \%(04) \rightarrow 12.6 \%(05) \rightarrow 26.8 \%(06)$

- 연수과정의 표준화 및 정례화

- 효과적인 기본과정 운영방향 수립

- 기본과정을 일정기간 지속운영

(3년 또는 5년)

- 기관간 약정을 통해 안정적 사업운영

- 현지연수, 제3국 연수 점진적 확대

- 직업훈련 등 실습형 교육은 현지연수를 통 해 수혜인원 확대 및 기술전수효과 제고 ※ 미국, 호주, 일본 등은 현지연수를 적극 운영 중 (50\%이상)

- 대륙별 거점국가를 선택, 제3국연수 확대 실시 
※ KOICA-싱가폴 공동연수 과정 중 일부를 싱 가폴의 CLMV 연수센터를 활용한 현지연수로 운영('04 )

- 기획 및 평가 기능강화

- 국제기구 공동사업 확대를 통한 사업기획의 선진화 및 선진원조기구의 Management Tool 도입추진

- 국제기구와의 공동사업 확대를 통한 기획능 력 강화

- 국민참여 프로그램 확대

- 「주니어 코디네이터제도 활성화, 초중생 연 수센터방문 정례화」등 민간참여 프로그램 지속 개발

- 다양한 민간참여 프로그램 개발로 협력사업 홍보 및 개발인식제고

※ 초 - 중등 학생들에게 국제협력연수센터 개

방, 주말 민박제도 운영, 연수생들과의 만 남, 지방자치단체와의 연결, Foster Family 제도 등

학생 코디네이터 : 고등학생들을 시내견학 시 코디네이터로 활용 ('06 )

- 전문기관과 파트너쉽 강화

- 전문기관과 공동연수과정 개설 적극모색

- 타부처 및 민간과의 공동사업 추진을 적극 유도하여, 동반자 관계로 발전 ※ 원자력기술, 선거관리 등 국내 Co-funding을 통한 2개 분야 사업추진 ('06)

\section{2) 해외봉사단파견}

- 국별 · 분야별 봉사단 프로그램화 추진

- 파견형태를 다양화하고 민간부문과의 연계
도 강화

- 시니어봉사단 : 2005 년 파견인원은 21 명으 로 신규파견 인원의 $3 \%$

- 긴급재난구호봉사단 : 남아시아 지진해일 지원 등 총 199 명 활동

- 산학협력 대학봉사단 : 2005년말 현재 6개 대학과 협정체결, 총 87 명 파견

- KOICA-NGO 봉사단 : 2004년 이후 11 개 $\mathrm{NGO}$ 단체 9개국 73명 지원

2006년부터 해외원조단체협의회에 예산을 지원, $\mathrm{NGO}$ 단체에서 직접 해외봉사단을 파견 할 수 있도록 지원

- 타사업과의 연계강화를 통한 사업효과 제고 - 필요한 경우, 프로그램형 사업수행에 봉사 단 투입

※ 프로그램사업에 인적요소로 해외봉사단을 연계

- 우수자원 확보방안 강구

- 전문기술 및 경험을 보유한 중장년층의 해 외봉사 참여기회 확대

- 개도국 수요의 전문화 및 다양화에 부응 ※ '05년 기준, 시니어 비중은 전체인원의 $3 \%$ 로 향후 $10 \%$ 수준까지 확대 추진

- 농림수산, 이공계 등 우수자원 확보를 위해 국제협력요원 확대

- 업무의 전문화 · 체계화 추진

- 단원 국내훈련 등 단순 반복업무는 외부기 관 업무위탁 확대

- 직원은 기획 및 평가 업무에 주력

- 수요발굴, 모집 · 선발 업무의 체계화

- 단원관리 및 활동지원 업무의 전문화 
- 우수자원 확보를 위한 홍보강화

- 좀 더 효과적이고 인상적인 홍보전략 개발 ※ 주요 일간지, 지방지, 대학신문 등의 인쇄매체

및 인터넷 광고

- TV등 주요매체를 통해 국민들에게 강한 이 미지 전달

- 귀국봉사단을 통한 홍보활동 및 홍보채널 다양화

\section{3) 프로젝트 - 개발조사}

- 하드웨어 위주에서 소프트웨어 지원으로 점차 전환

- 제도구축, 지식전달형 사업 등 소프트웨어 부분 확대

- 선진원조국의 경우 컨설팅 비중이 높은 점 과 개도국 지속발전 등을 고려, 소프트웨어 가 점차 증가하는 추세

- 다만, 사업의 결과가 무형적이기 때문에 수 원국에서 이를 활용하지 않을 경우, 비효율 적이므로 신중하게 추진

- 개발 컨설턴트 적극 활용

- 분야별로 전문화된 민간 컨설팅 그룹 발 굴·육성 필요

- 분야별 사업시행단체 및 기업의 사업결과를 평가하여 우수기관 육성

- ODA 설명회 등을 통해 협력사업 참여 주체 의 다변화 노력

- 개발사업 추진절차 신속화

- 사업추진 지연요소 개선을 통해 사업집행의
신속성 제고

- 사업개시 전년도에 사전조사를 종료하여 사 업추진기간 단축

- 정부간 협의절차 신속화

※ 협의의사록체결 후 신속하게 사업자 선정절차 를 취하고 사무소 및 공관을 통하여 신속하게 구상서 교환

- 사후관리 내실화

- 사업수행업체 계약시 기자재 사후관리 조항 강화

- 프로젝트 운영지원, 기술자문, 부품지원 등 체계적인 사후관리를 통해 지속발전 가능성 제고

4) 전문인력파견

- 사업간 연계 강화

- 국별 원조프로그램 수립을 위한 조사, 협의 (선진국 일반적 형태)

- 수원국의 관련분야 정책수립 자문 및 제도 구축 지원업무 수행

- 일반전문가, 팀제 전문가, 프로그램 전문 가 등

a 전문가 Pool 시스템 개선

- 전문가 Pool 시스템 개선을 통한 우수전문 가 상시 확보체제 구축

- 검증된 전문가와 자격요건만 갖춘 잠재적 전문가로 구분 · 운영

- 기 파견자의 활동성과 및 보고서 관리 체제 구축

- 태권도사범파견사업 외부 위탁용역 검토 
- 관리 및 운영업무 아웃소싱 검토

- 태권도협회 또는 국기원 등 비영리기관에 위탁, 태권도 전문기관으로 하여금 체계적 이고 집중적으로 관리토록 개선

- 의사파견사업 개선방안 검토

- 수원국 의료서비스 제도 및 능력향상을 위 한 기술이전 방식으로 전환

5) NGO 지원

- $\mathrm{NGO}$ 지원예산 확대

- 국별 프로그램 추진에 있어 $\mathrm{NGO}$ 참여 확대 방안 마련

- 국별지원사업외 $\mathrm{NGO}$ 역량강화 지원예산 규모도 확대

※ 1개 사업당 지원예산 규모를 확대하여 실질적 인 사업성과달성 및 우량사업 발굴

- 다년간 지원 제도 도입

- 중기지원을 통해 안정적이고 지속발전가능 한 사업추진

- 민간단체는 안정적으로 사업을 추진하고, $\mathrm{KOICA}$ 는 체계적 사업관리 및 평가 가능 ※ 신청단체 및 사업관련 자격요건, 심사기준 등 상세내용은 추후 확정하여 2007년도부터 도 입 예정

- $\mathrm{NGO}$ 역량강화 프로그램 확대

- 단기적으로는 다양한 Study Tour 프로그램 확대, KOICA 주관 워크샵 개최, 해원협과의 협력확대를 통해 다양한 프로그램 추진

- 중장기적으로는 대학 등과의 협력을 통해 개발 $\mathrm{NGO}$ 관련 강의과정 개설, 사업현장
탐방 프로젝트 공모제 등 실시

- $\mathrm{NGO}$ 중점지원국가 선정

- KOICA 국별전략 수립후, NGO 중점협력지 역 및 분야 제시

- $\mathrm{NGO}$ 들이 동 전략에 부합하는 사업을 수행 하도록 유도

* 예시 : 아프리카 지역은 식수공급, HIV/AIDS 관련사업 우선지원, 최빈국 지원우대 등

6) 다자협력

- 다자협력체제 재정립

- 단순 현금공여는 지양하고 국제기구와의 공 동사업 발굴

- 무상협력사업 수행의 효율성 제고를 위한 전략적 접근 필요

- 다자협력의 국제동향 파악 강화

- 단내외 세미나, 연구용역, 국제회의 참가 등 정보수집 활동 강화

- 선진공여국 및 DAC에 대한 최신 정책동향 파악 강화

* KOICA내 ODA 연구기능 강화, OECD 회의참석 등을 통해 정보수집 및 각종 논의 적극참여 필요

- 다자협력 평가시스템 마련

- World Bank, UNDP 등 핵심 다자기관과의 평가네트워크 구축필요

- 다자간 지원성과에 대한 정보 및 관련자료 교환 등

7) 홍보

- $\mathrm{ODA}$ 대국민 인지도 향상 노력 강화 
- 청소년참여 프로그램 확대 개발

- 국제협력 특강 및 글짓기 공모전 등 활성화

※ 2005년 초중고교생 대상 국제협력 특강이 237개교에 실시하여 전년대비 $570 \%$ 증

※ KOICA 글짓기 공모전 시상확대 및 해외현장 방문을 통해 393개 학교가 참여, 전년대비 $60 \%$ 증

- 홍보수단의 다양화

- 대중매체를 통한 홍보강화

$-\mathrm{TV}$, 일간지 등 파급효과가 큰 언론매체를 통해 홍보활동 강화

※ 합동취재 3 회, 대언론홍보 총 1,133회(신문, 방송, 잡지, 인터넷), 광고홍보 12회, 유관기관 연계홍보 3회 등

- 다양한 채널을 활용 "KOICA 알리기” 주력

- 그간은 사업내용 홍보에 주력, 앞으로는 $\mathrm{KOICA}$ 기관홍보도 강화
- 기획 홍보, 계기 홍보, 온라인 홍보, 이벤트 홍보, 간담회 및 연찬회, 국제협력 연수, 여 론 주도층 홍보 등

- 언론사 해외현장 취재 지원 및 업무협조약 정 체결을 통하여 협력사업 및 $\mathrm{KOICA}$ 소개 등

※ KBS 다큐멘터리(2편, '05.10, 12), 중앙일보 UN 창설60주년 기획기사6회, '05.10 - 11)

※ KOICA-연합뉴스간 업무협조 약정 체결 ('05.2), 'KOICA 리포트' 등 게재

- 정부의 국가이미지 제고노력에 적극참여

- 정부의 국가이미지 제고노력에 적극 동참함 으로써 $\mathrm{KOICA}$ 사업홍보와 해외홍보 협조 네트워크 구축

※ 국정홍보처, 정부부처 등과의 국제개발협력 공 동홍보 노력 등 